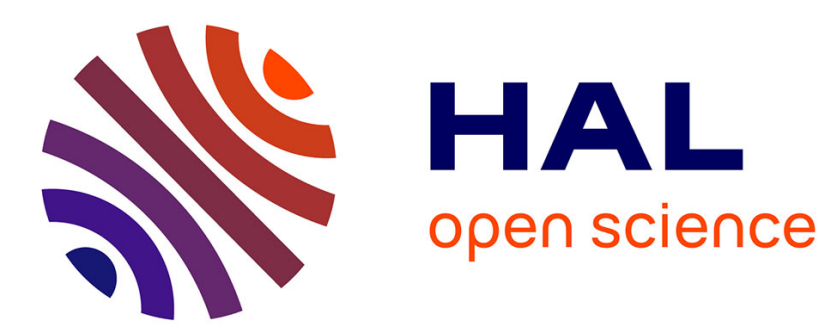

\title{
Thermobimetals Mechanical Properties Produced by Explosive Welding with Rolling
}

\author{
V. Gulbin, A. Kobelev, D. Borissov
}

\section{To cite this version:}

V. Gulbin, A. Kobelev, D. Borissov. Thermobimetals Mechanical Properties Produced by Explosive Welding with Rolling. Journal de Physique IV Proceedings, 1997, 07 (C3), pp.C3-49-C3-54. 10.1051/jp4:1997311 . jpa-00255394

\section{HAL Id: jpa-00255394 https://hal.science/jpa-00255394}

Submitted on 1 Jan 1997

HAL is a multi-disciplinary open access archive for the deposit and dissemination of scientific research documents, whether they are published or not. The documents may come from teaching and research institutions in France or abroad, or from public or private research centers.
L'archive ouverte pluridisciplinaire HAL, est destinée au dépôt et à la diffusion de documents scientifiques de niveau recherche, publiés ou non, émanant des établissements d'enseignement et de recherche français ou étrangers, des laboratoires publics ou privés. 


\section{Thermobimetals Mechanical Properties Produced by Explosive Welding with Rolling}

V.N. Gulbin, A.G. Kobelev and D.E. Borissov

NIKIMT, 127410 Moscow, Russia

Abstract. We used explosive welding with rolling to produce thermobimetals on the basis of beryllium bronze and alloys of nickel. It gave us possibility to obtain magnetic and nonmagnetic thermobimetals possessing high physical and mechanical properties.

\section{INTRODUCTION}

Thermobimetals are being applied as thermoelements of adjuster, automatical preservatives etc. In the modern time there are increased requires for reliability and durability of thermobimetals in addition industry has purpose to increase quality of thermobimetals.

Elements of thermobimetal must posses residual of coefficients of line expending for creating of most bend moment at data temperature interval and also providing event bending if temperature suddenly increases from working temperature. In addition physical and mechanical properties of elements of thermobimetal must provide firm joint on contact surface and possibility of further treatment (shearing, bending, forging).

Thermobimetal must not receive residual deformation and must not change its electrical resistance during using. Elements of thermobimetal must be non-magnetic for exclude its reaction on magnetic fields existing in device during working.

Thus as elements of thermobimetals are the following materials. First class: active element is beryllium bronze БрБ2, resilient passive element is titanium BTI-0 and alloy46 XHM. Second class: active element is aluminum АДI, passive elentent is beryllium bronze БрБ2. 
For producing of magnetic thermobimetal we use alloys $75 Г Н Д$ and $36 \mathrm{H}$.

Thickness of these plates: БрБ2 $-0.8 \mathrm{~mm}$, BT1-0 $-2.0 \mathrm{~mm}$, 46ХНМ and АД $1-3.0 \mathrm{~mm}, 75 Г Н Д-12 ~ \mathrm{~mm}, 36 \mathrm{H}-9 \mathrm{~mm}$.

\section{RESEARCH}

Thermobimetals are made usually as plates and tapes $0.1 \div 2.5 \mathrm{~mm}$ of thickness $[1,2]$. Analysis of different methods of producing of thermobimetals has shown that best method is combined method including explosive welding and plastic deformation (rolling) of bimetal workpiece [2].

Explosive welding is performed on parallel schema providing more uniform properties of weld joint. Non-magnetic thermobimetal is performed by welding of back schema i.e. projectile plate is more thick [3]. This schema guarantees more steadies results of welding. Contact surfaces of plates were grinded and degreased. As explosive we used ammonia-saltpete commercial explosive. During experiment we changed strain rates $(1850 \div 3550 \mathrm{~m} / \mathrm{s})$ and dimension of strain pressure $(10 \div 40 \mathrm{kbar})$.

Joints of performed thermobimetals were tested by ultrasonic flow detector and by bending and by torsion. Fractures were not revealed. Investigations of toughness shown that quality of welding of layers $36 \mathrm{H}$

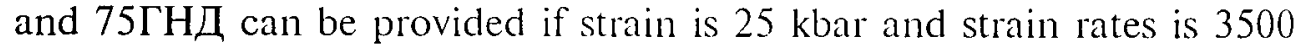
$\mathrm{m} / \mathrm{s}$. At these conditions toughness of layers during breaking off is $350 \div 400 \mathrm{mPa}$. Measurement of microhardness shown that hardness of material increased due to impact loading. Thus hardness of alloy $36 \mathrm{H}$ increased from $2060 \mathrm{mPa}$ on surface to $2680 \mathrm{mPa}$ in joint zone,

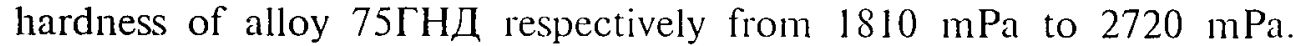
Also there is loss of strength in joint zone because high temperature is appeared due to transformation of part of deformation work to heat.

During welding there are changing of structure and properties of metals and creation of new phases possessing as rule lower plastic characteristics. Thus we can observe local field of solutions on the basis of copper and titanium in joint zone of bimetal БрБ2+BT1-0 (fig.1). 


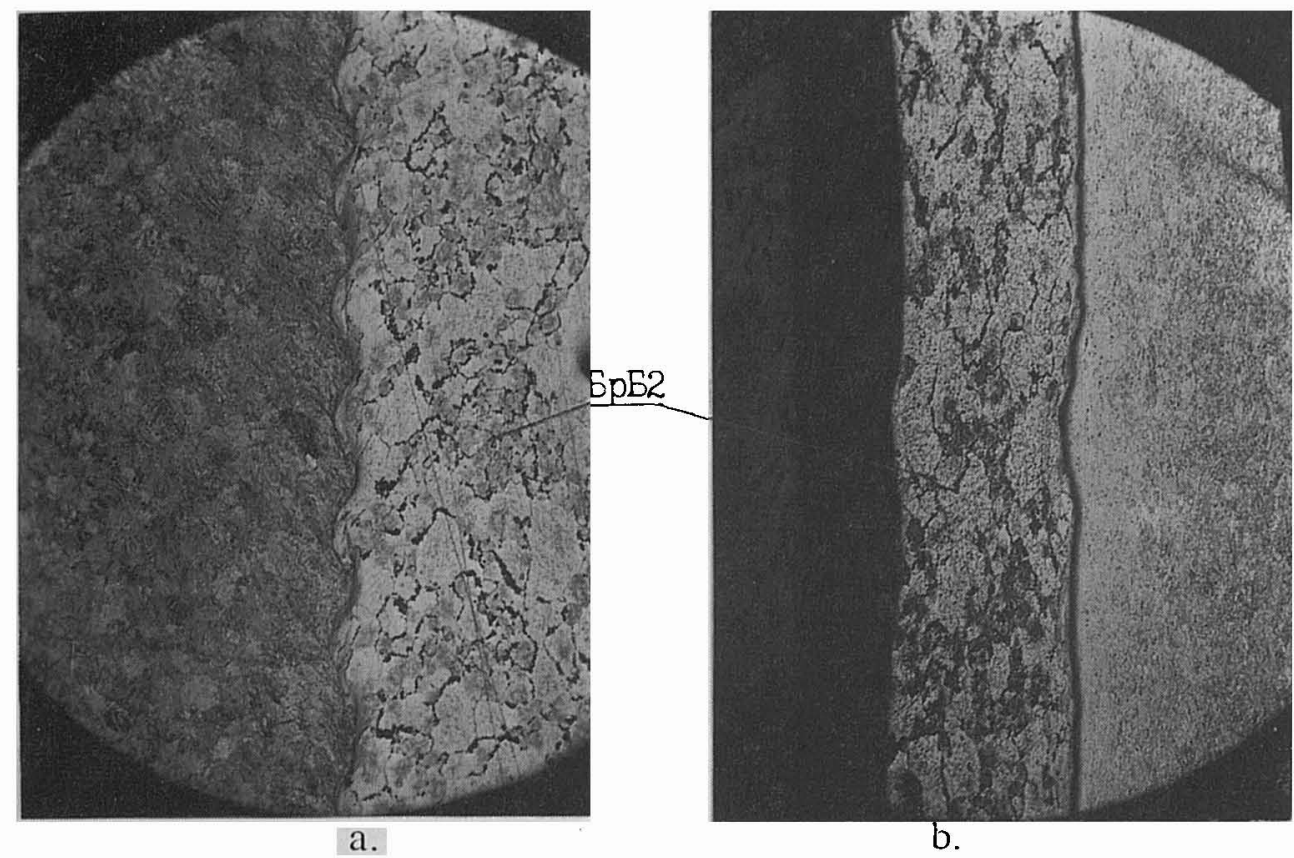

Fig.1. Microstructure of joint zone thermobimetal БрБ2+BT1-0 after explosive welding (a) and after rolling (b), $\times 50$.

Alloy BT1-0 has got structure of $\alpha$-solid solution with twin crystals. It shows that material is subjected by hit strain deformation during explosive welding.

Beryllium bronze has got structure of $\alpha$-solid solution with high disperse inclusions of $\gamma(\mathrm{Cu}, \mathrm{Be})$-phase situated both at grain boundaries and within of grain. After explosive welding microhardness of copper is $2900 \div 3200 \mathrm{mPa}$, microhardness of titanium is $2210 \div 2680$ $\mathrm{mPa}$, microhardness of joint zone is $3900 \div 5500 \mathrm{mPa}$ (fig. 2).

At explosive welding of beryllium bronze and alloy $46 \mathrm{XHM}$ in joint zone local field of white phase of intermetallic type are created. Microhardness of these fields is $3440 \div 3870 \mathrm{mPa}$ (fig.3). 


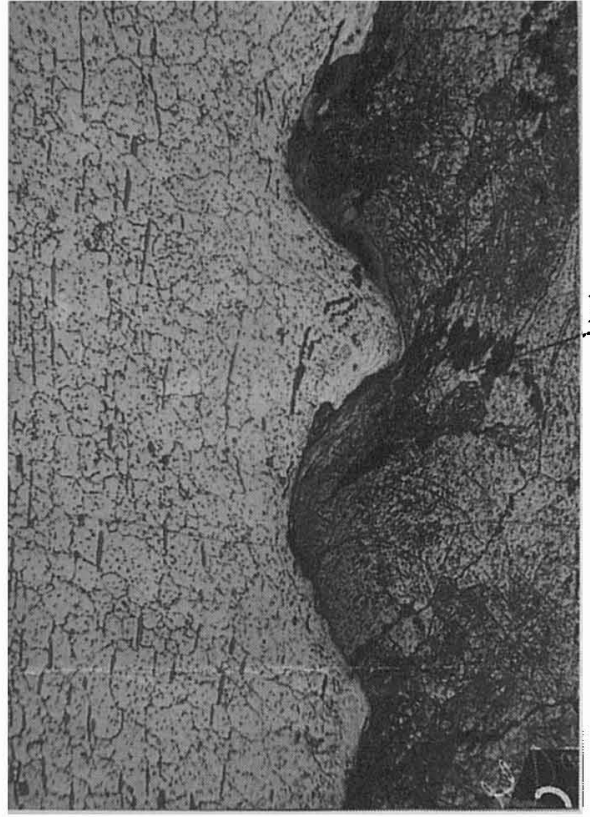

a.

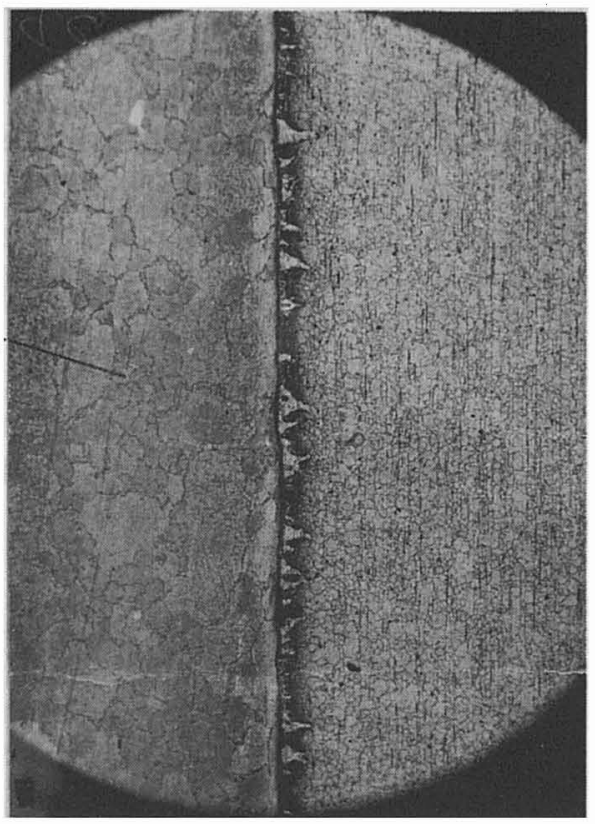

b.

Fig.2. Microstructure of element БрБ2 after explosive welding (a), $\times 100$ and after rolling (b), $\times 200$.

Alloy 46XHM has got structure of $\gamma$-solution of $\mathrm{Cr}$. in Ni. with big quantity of hardening phase distributed uniformly. Microhardness of this phase increases from 3900 to $5000 \mathrm{mPa}$.

Most of quantity of inclusions of brittle intermetallic phase is observed in thermobimetal performed from beryllium braze and aluminum. Microhardness of these phases is $3900 \mathrm{mPa}$.

Welded bimetals are subjected by rolling and heat treatment to reach necessary size and physical and mechanical properties and structure. Non-magnetic thermobimetals have been rolled without heat with rolling mill because bronze has loss of plasticity in temperature interval $200^{\circ} \div 600^{\circ} \mathrm{C}$ and higher $825^{\circ} \mathrm{C}$ [4]. Deformation is $85 \%$. Hardening of metals is result of deformation.

Thus after rolling of bimetal БpБ2+BT1-0 microhardness of bronze is $2770 \div 3210$, microhardness of titanium is $2210 \div 2680 \mathrm{mPa}$, microhardness of joint zone is $5230 \div 6690 \mathrm{mPa}$. Thermobimetals are 
annealed to decrease harden and stress. Performed non-magnetic thermobimetalic tapes of thickness $0.4 \div 1.6 \mathrm{~mm}$ are used for producing of contact elements for electronically tools. Thermobimetal $36 \mathrm{H}+75 Г Н Д$ is heated till temperature $870 \div 880^{\circ} \mathrm{C}$ during lhoure then thermobimetal is rolled from thickness $20 \mathrm{~mm}$ till $4 \mathrm{~mm}$.

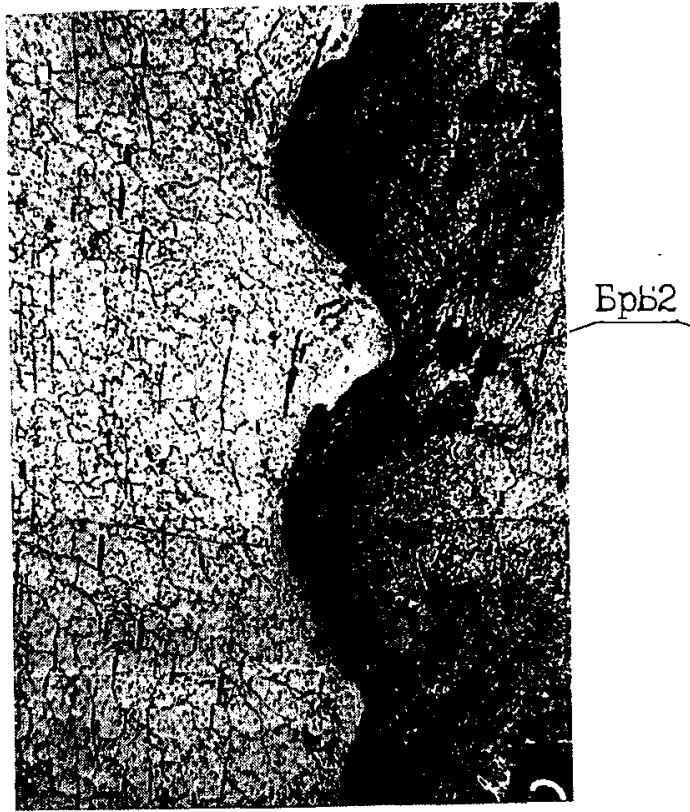

a.

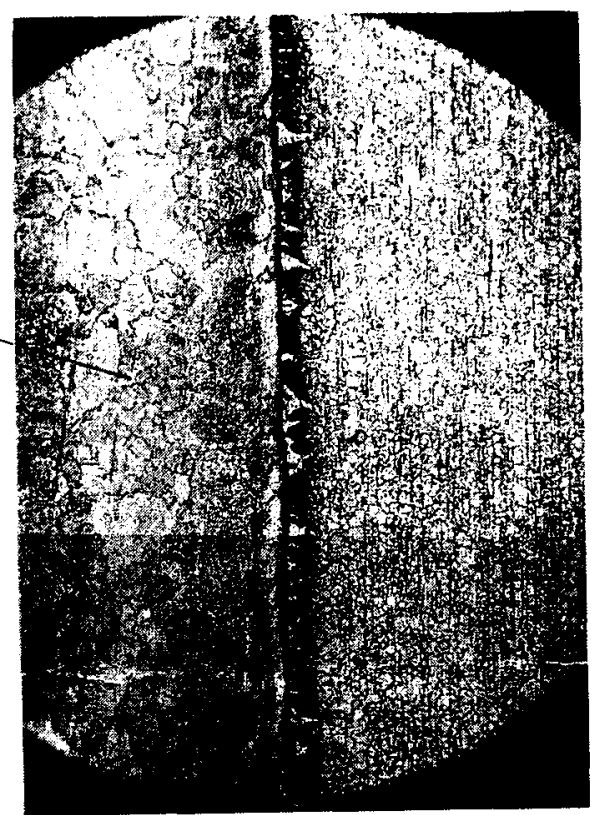

b.

Fig.3. Microstructure of joint zone of thermobimetal БрБ2+46XHM after explosive welding (a), $\times 200$ and after rolling (b), $\times 50$.

Tensile tests of heat rolled specimens show strength is $\sigma_{\mathrm{b}}=400 \div 450 \mathrm{mPa}$ but joint zone has higher hardness $(220 \div 240 \mathrm{mPa})$. Further rolling till thickness $2 \mathrm{~mm}$ gives significant hardening of thermobimetal and hardness increases till $730 \div 770 \mathrm{mPa}$. Plasticity increases till $\delta=2 \div 3 \%$. Therefore intermediate anneal is necessary. Investigations show that temperature of anneal must be $800^{\circ} \div 860^{\circ} \mathrm{C}$ and duration must be 2 hours.

Thus we have developed technology of producing of magnetic and non-magnetic thermobimetals including explosive welding and rolling. 
Tests of performed thermobimetals show its reliability at working in verity electronically tools.

\section{References}

1. U.A.Bashnin, F.B.Ulanovsky, I.V.Perepelitsa. Thermobimetals.- M.: Mashinostroenie. 1989. - $134 \mathrm{~s}$.

2. A.G.Kobelev, I.N.Potapov, E.V.Kuznetsov. Technology of sandwich metals. - M.: Metallurgia, 1991. - 248 s.

3. A.V.Krupin, A.G.Kobelev, V.J.Soloviov. Toughness of joining of loyers of bimetal at different schemas of impact loading. / $\mathrm{Sb}$. "Theory and technology of metals' treatment by pressure". M.: Metallurgia, 1976 (MISiS. Science paper №94), 61-64 s.

4. S.I.Gubkin. Metals' deformation. - M.: Metallurgizdat, 1953. $-248 \mathrm{~s}$. 